\title{
MULTICRITERY MODELING IN THE DECISION-MAKING PROCESS OF CREDIT LINES AT BANCO DO BRASIL
}

\author{
Bruno Oliveira Pinto Cardoso ${ }^{a}$, Hugo Saba Pereira Cardoso ${ }^{b}$, José Vicente Cardoso \\ Santos $^{b, c}$, Renelson Ribeiro Sampaio ${ }^{c}$
}

a, Banco do Brasil, Brasil,

b, Universidade Estadual da Bahia (UNEB), Brasil,

c, Centro Universitário SENAI-CIMATEC, Brasil,

\begin{abstract}
In this research, Banco do Brasil's credit lines are considered in the aspect inherent to its feasibility criteria and investments in the business area, since it is a valuable financial tool to meet the needs of liquidity, working capital and refinancing in times of crisis. The general objective is the modeling of credit lines using multicriteria methodology for the offer and selection of credit lines for legal entities; and the specific objectives are the creation of a weighting algorithm script for scoring corporate profile and mapping the normative instructions that guide the definition of the credit line qualification criteria. The research methodology is the literature review based on bibliographic references, information searches related to credit lines offered to clients in the form of legal entities and research in the Banco do Brasil universe. As a legacy, there is the registration of another proposal for a strategy for selecting credit lines and offering recommendations for lists of actions in dealing with the topic and the like.
\end{abstract}

Keywords: Credit lines. Multicriteria methodology. Banco do Brasil.

\section{MODELAGEM MULTICRITÉRIO EM PROCESSO DECISÓRIO DE LINHAS DE CRÉDITO NO BANCO DO BRASIL}

Resumo: Nesta pesquisa são consideradas as linhas de crédito do Banco do Brasil no aspecto inerente aos seus critérios de viabilidade e aplicações na área empresarial, visto ser ferramenta financeira de grande valia para suprir as necessidades de liquidez, capital de giro e refinanciamentos em tempos de crise. $O$ objetivo geral é a modelagem de linhas de crédito com uso de metodologia multicritério para a oferta e seleção de linhas de crédito para pessoa jurídica; e os objetivos específicos são a criação de roteiro algoritmo de atribuições de pesos para pontuação de perfil de pessoa jurídica e o mapeamento das instruções normativas que norteiam a definição dos critérios de enquadramento de linha de crédito. A metodologia de pesquisa é a revisão de literatura pautada nas referências bibliográficas, nas pesquisas de informações referentes as linhas de crédito ofertadas para clientes na modalidade de pessoa jurídica e em pesquisa-ção no universo do Banco do Brasil. Como legado fica o registro de mais uma proposta de estratégia de seleção da linhas de crédito e oferta-se recomendações de listas de ações no trato do tema e afins.

Palavras-chave: Linhas de crédito. Metodologia multicritério. Banco do Brasil. 


\section{INTRODUCTION}

Banco do Brasil, object of this research, is constituted in the form of a mixed capital company, with the participation of the Federal Government in $68.7 \%$ of the shares, so that today it operates with more than 18,000 service stations distributed throughout the country, among branches and several service stations, in addition, it is present in 23 countries, and according to the bank's own data, it has more than 100 thousand employees ${ }^{1,2}$.

Like any large financial institution today, Banco do Brasil offers diversified credit lines, adjusted to the established criteria so that the process of choosing a credit line that is more appropriate and compatible with the client's profile is defined by the Bank but is a practice not yet automated and requires management participation in a laborious way and prone to errors of all kinds ${ }^{3}$.

With this scenario in mind, the general objective of this research is the modeling of credit lines using a multicriteria methodology for the offer and selection of credit lines for legal entities. The specific objectives are the creation of a weighting algorithm script for scoring corporate profile and mapping the normative instructions that guide the definition of credit line framing criteria.

In order to consolidate these objectives, a methodology is adopted that is backed by a literature review, of a historical and documentary nature ${ }^{4}$, based on books, articles, dissertations and theses which version on business credits and multicriteria decision support methodology as well as study of case with action research with immersion in a real scenario found in "Banco do Brasil" and in the Brazilian business market. It is, therefore, a hybrid research, as two classic methods are combined, the literature review with the case study of real data and hidden scenario, given the non-exposure of the data of the referred bank or of the listed companies as in claim for credit lines, however, the data provided are real and compatible with the current business scenario in Brazill ${ }^{4,5}$.

\section{METHODOLOGY}

\subsection{Generic methods}

In general, in the generic methods, to consolidate the primary elements of evaluation, actions are taken that culminate in interviews with decision makers, and the questions are developed in such a way that all the possibilities under analysis are listed with them ${ }^{6}$.

The descriptors, on the other hand, are constructed through the fundamental points of view, so that, for each credit line, there is a set of fundamental points of view, which are specific to each of the lines, which culminates in different cardinal scales for each line. and the construction of multicriteria models to support the specific decision-making process for each scenario unfolds by proposing alternative methods, despite the same philosophy and fundamental principles of the MCDA (Multicriteria Decision Support Methodology) ${ }^{7}$. 


\subsection{Credits and characteristics of decision-making processes in Brazil}

Traditional credit is the granting of an amount of money or other client, and is committed to return the amount within a predetermined period and with interest ${ }^{8}$. Therefore, the individual or company receives an advance that must be returned in full and plus a calculated amount on capital.

The investigation of the banking relationship, however, follows other directions, abandoning the central issue of the value of the banking relationship for its direct stakeholders ${ }^{9}$ so that the business environment in the country must seek freedom of innovation and have very clear and defined rules in the execution financing projects.

Decision-making processes or decision problems can be seen as something analogous to a game, where nature chooses a state from the set of possible states and a decision maker with a function of choice through a function that represents the set of preferences that the decision maker has about a set of possible consequences ${ }^{10}$.

Still in this same line, the TODIM (Multicriteria Interactive Decision Making) $6,7,8$ method uses a multicriteria decision model based on a multi-attribute utility model where the decision maker's preferences are modeled in order to represent the multiple objectives related to the credit supply problem ${ }^{11}$.

Finally, it is possible to state that, in general, decision support methods, which use more than one argument or decision processes, are called multicriteria methods, so that Multicriteria Decision Support (MCDA) methods start from the assumption of that and finally the facilitator who will never be neutral and, therefore, will influence the outcome of the decision process ${ }^{12}$.

\subsection{Multicriteria Methods}

Formally, the multicriteria methods of decision support can be defined as an activity, or set of activities, in which the facilitator, in a scientific way, aims at obtaining elements that answer questions raised by decision makers in a decisionmaking process, so that these elements help in the process of understanding the decision $^{13}$.

Thus this, one can classify three types of actors, to mention: decision makers, representatives and the facilitator. Decision-makers are those to whom decisionmaking power has been formally or morally delegated; the representative, who is the actor assigned by the decision maker to represent him in the decision support process; and, finally, there is what is called Facilitator and who is also an actor in the decision-making process, since he will never be neutral in the decision support process and, therefore, influences him ${ }^{14,15}$.

In addition, the existence of a set of fundamental points of view (PVPs) that represents the facilitator's expertise and contemplates the grounds for the decision. Such set of fundamental points of view is perceived as paramount for the elaboration of guidelines for the evaluation of existing and future actions ${ }^{16}$.

Such properties demand concepts of intelligibility, consensuality, operability and isolability in such a way that the use of the characteristics of PVF's in a concomitant way allows them to reflect the facilitator's perception at that moment, reflecting their expertise and not disregarding the improvement of the same ${ }^{12,17,18}$. 
Thus, in general, relations between the banking system and companies contribute the development of a credit model, with a strong participation of the State, not only with regard to the administration of interest rates and credit conditions, but also in the direct provision of rules for the offer of credit that can be based on the requirements of the State itself and with criteria of interest to the institution and the client itself.

\section{RESULTS AND DISCUSSION}

\subsection{Credit lines modeling}

For a better understanding of the credit lines, it is essential to know the main characteristics that are necessary for each credit line as well as the separation into classes or categories. The aim is to build a map with this information, based on the questions that are asked to the clients so that the managers can, from the answers, search for the line or lines that fit the client's profile.

As a procedure, it is suggested that the Manager visits the client, or the client goes to the agency and in the conversation the need for credit arises, which triggers a process in which the Manager checks the normalization of the issues analyzed and seeks to define which concepts-key to that company thus generating the analysis process for this client that will be associated with its respective purpose according to Chart 1.

Table 1 Lines of Credit and their respective purposes

\begin{tabular}{|l|l|}
\hline \multicolumn{1}{|c|}{ Credit Line } & \\
\hline Quick Turn Purpose \\
\hline $\begin{array}{l}\text { Anticipation of Credit to } \\
\text { Tenants (ACL) }\end{array}$ & Reinforcement of Working Capital \\
\hline BNDES Card & Finances machines, equipment, production goods. \\
\hline Guaranteed account & Reinforcement of Working Capital \\
\hline Checks Discount & Anticipation of the net sales value. \\
\hline Business Finame & For the purchase, production or sale of machinery. \\
\hline Finame Empresarial PSI & $\begin{array}{l}\text { Finance the acquisition and production of machines via } \\
\text { BNDES. }\end{array}$ \\
\hline Finame Modermaq & Finance the purchase of machinery and equipment \\
\hline Giro Flex Company & $\begin{array}{l}\text { Reinforcement of Working Capital and acquisition of goods } \\
\text { and services. }\end{array}$ \\
\hline $\begin{array}{l}\text { Giro Empresa Flex - Structured } \\
\text { Releases }\end{array}$ & $\begin{array}{l}\text { Capital strengthening and financing for the acquisition of } \\
\text { goods and services, export credit. }\end{array}$ \\
\hline Giro Mix PASEP & Reinforcement of working capital \\
\hline Cash Receivables & Reinforcement of working capital \\
\hline Proger Turismo Investment & $\begin{array}{l}\text { Financial support for working capital associated with projects } \\
\text { in the tourism sector. }\end{array}$ \\
\hline Proger Urbano Empresarial & $\begin{array}{l}\text { Financial support for investments with working capital for } \\
\text { micro and small companies. }\end{array}$ \\
\hline
\end{tabular}

The records that this set of credit lines, their purposes and criteria can be changed in the interest of the institution, in addition to the fact that each credit line 
has peculiar characteristics and that define them as conditions or prerequisites for adhering to the company and this analysis is also made by the Manager.

\subsection{Determination of the profile of the clients under analysis}

In this modeling, it was decided to adopt a set with five different customer profiles under analysis, so that each profile starts to represent a set of customers with the same economic and situational category.

Using the strategy of algorithmic assembly of multicriteria methods, where each possible class of credit lines and their respective conditions or directions for adherence to them are described as observed in the mathematical relationship and in the tables below, according to questions that managers send to legal entities through their representatives and on the fundamental and inherent issues of the credit claim in order to describe, with the TODIM method ${ }^{6,7,8,11}$, where there is a reflection of the variables used in the problem under analysis, as well as their normalized weights and values, ie:

$$
\text { Punctuation }=\left[\begin{array}{l}
(F+P A+R C+R O+L C V+L R+C C)^{\{0,1\}}+ \\
\frac{(L L+G)^{\{1,2,3,4,5\}}}{5}
\end{array}\right] * 10 / 9 \quad \text { Eq. } 1
$$

where the variables and notation can be understood as being: " $F$ " the purpose, "PA" the target audience, "RC" the client risk, "RO" the operation risk, "LCV" the current credit limit, "LR" the release of funds, and the "CC" the Cielo affiliation, collection or custody, and the "LL" the line limits, and "G" the guarantees; and, the values in exponent in the relations the discrete ranges of variation are their weights, thus totaling a maximum score of 9 , since the expressions already assume the normalization of these values with the division by their maximum values, thus having the maximum points in total for each analysis and that the maximum score can be thus represented

$$
\text { Punctuation }=\overbrace{\left[\begin{array}{l}
F=0 \vee P A=0 \vee R C=0 \vee R O=0 \vee L C V=0 \\
\vee L R=0 \vee C C=0 \vee L L=0 \vee G=0=0
\end{array}\right]}^{=0} \quad \text { Eq. } 2
$$

In other words, the nullity of the score is imposed when in the decision-making process, some of the variables under analysis are canceled, due to some of their own conditions of nullity, the other criteria are zeroed out..

Thus, with the above, this process reflects the expertise of analyzing the credit lines and if all are or obtain, in the analysis of the management technician, their respective maximum values, the totalization is obtained with the sum of all their values.

In addition, an expression is used that determines a weighted average by class and category of questions, where when the first six categories are null, the total score is immediately canceled, that is, when the purposes, target audience, risk customer, operation risk and the current credit limit are set to null, the respective 
score is null, the same also applies to credit guarantees, which, when none exist, also set the respective score.

\section{CONCLUSION}

This research then presents a proposal for modeling the supply of credit lines in banks as well as the description of several lines, their characteristics and even the normalization of weights in the attribution, or not, of these values. In addition, an algorithmic modeling of how to weight and numerically normalize this score was also suggested so that it is possible to generate a numerical scale scored in the analysis of the credit supply.

The existence of several methodologies for the qualification and offer of business credits was also registered, however the unanimity of a specific method for the granting of business credits is not true, leaving the institution or even the respective Manager, in order to model a way to select and classify these lines according to inhabited customers.

With this, the research objectives are consolidated in the proposal for modeling credit lines as well as the creation of a weight assignment algorithm with the description of normative instructions associated with a normalizable numerical scale. These procedures can be implemented in simple software (spreadsheets and even high-level languages, etc.) and the Manager himself can use, that is, a solution perfectly adjustable to classic credit concepts, multicriteria methodology and demands and applications on the day day to day management.

In this way, the legacy of this research is more a credit assessment instrument, more an argumentation strategy for the hierarchical indication of these same lines for the business area, with the advantage of being quick to apply and transparent to the investor, the Manager and employees, as well as for the client, thus generating an understanding of any pending issues that can be resolved for a possible new analysis.

Finally, it is also recommended that similar procedures and spreadsheets be created for other areas, such as rural and microcredit areas, for example, in addition to the implementation of applications for cell phones, so that it is done in an automated way and that available on these devices so that the managers of each area can give an immediate response to the client during on-site visits.

In this sense, it is recommended, for future work, a deeper use of credit rules, their legal bases, analysis of trends and megatrends, as well as a more in-depth literature review in the area, with the purpose of covering more credit lines. in order to create a standardized model that serves as a support tool for decision making, not only for the legal entity area, but for other areas.

\section{Acknowledgments}

We thank SENAI CIMATEC, Banco do Brasil, UNEB (Universidade do Estado da Bahia), CNPq and FAPESB for financial support. 


\section{REFERENCES}

${ }^{1}$ BRESSER-PEREIRA, Luiz Carlos. A reforma do estado dos anos 90: lógica e mecanismos de controle. Lua Nova: Revista de Cultura e Política, São Paulo, n. 45, p.49-95, 1998. Disponível em: <http://www.clad.org.ve/fulltex/0030101.html>. Acesso em: 28 ago. 2016.

2 BANCO CENTRAL DO BRASIL. Disponível no site https://www.bcb.gov.br/pre/ composicao/bm.asp. Acessado em 12 jul. 2020.

${ }^{3}$ BRANDÃO, M. A. L. Estudo de alguns métodos determinísticos de otimização irrestrita. Uberlândia, 2010. 87p.

${ }^{4}$ CERVO, A. L. \& BERVIAN, P. A. Metodologia Científica. 6a ed. São Paulo, Makron Books. 2011.

${ }^{5}$ RUIZ, João Álvaro. Metodologia científica: guia para eficiência nos estudos. $9^{a}$. ed. São Paulo: Atlas. 2015.

${ }^{6}$ ENSSLIN, L; NETO, G. M.; NORONHA, S. M. Apoio à Decisão - Metodologia para Estruturação de Problemas e Avaliação Multicritério de Alternativas. Florianópolis: Insular. 2001.

${ }^{7}$ CORREAA, C. E. Construção de um Modelo Multicritério de Apoio ao Processo Decisório. Florianópolis - Brasil, 1996. Dissertação de Mestrado. Depto. De Engenharia de Produção, Universidade de Santa Catarina.

${ }^{8} \mathrm{ANDRADE}, \mathrm{E}$. L. Introdução à pesquisa operacional: métodos e modelos para análise de decisões. Rio de Janeiro: LTC, 2009.

${ }^{9}$ ALVES, Sérgio D. S.; SOARES, Marden Marques. Democratização do crédito no Brasil: atuação do Banco Central. Banco Central do Brasil, 2004. Disponível em: <http://www.bcb.gov.br>. Acesso em: 12 jul. 2020.

${ }^{10}$ KEENEY, R. L.; RAIFFA, H.; Decision with Multiple Objectives: Preferences and Value Trade-offs. John Wiley \& Sons. 1976.

${ }^{11}$ RAGSDALE, C.T. Modelagem e análise de decisão. São Paulo: Cengage Learning. 2009.

12 BANA E COSTA, C. A. Apoio à Tomada de Decisão segundo Critérios Múltiplos. IST/CESUR. Lisboa. 1986.

${ }^{13}$ ROY, B. Decision science or decision-aid science. European Journal of Operational Research 66. p. 184-203. 1993. 
${ }^{14}$ SCHWARZ, R. M., The Skilled Facilitator. San Francisco: Jossey-Bass.1994.

${ }^{15}$ COSTA NETO, Yttrio Corrêa. Bancos oficiais do Brasil: origem e aspectos do seu desenvolvimento. Brasília: Banco Central do Brasil, 2004. 82 p.

${ }^{16}$ GOMES, L. F. A M.; LIMA, C. F. S.; Tomada de Decisão Gerencial: Enfoque Multicritério. $3^{\text {a }}$. ed. rev. atual. e ampl. São Paulo: Atlas. 2092.

${ }^{17}$ GOMES, L. F. A. M. Teoria da Decisão. São Paulo: Thomson Learning. 2004.

${ }^{18}$ ROY, B. VANDERPOOTEN, D. The European School of MCDA: Emergence, basic features and current works. Journal of Multicriteria Decision Analysis, v. 5, pp. 22-38, 1996. 